\title{
Distributive Justice and Customer Post-Complaint Behaviour of Fast Food Industry in Rivers State, Nigeria
}

\author{
Gibson Chituru Ogonu, N. Gladson Nwokah, Beatrice Chinyere Acee-Eke \\ Department of Marketing, Rivers State University, Port Harcourt, Nigeria \\ Email: gibsonogonu@gmail.com,nwokah.gladson@ust.edu.ng
}

How to cite this paper: Ogonu, G.C., Nwokah, N.G. and Acee-Eke, B.C. (2019) Distributive Justice and Customer Post-Complaint Behaviour of Fast Food Industry in Rivers State, Nigeria. Journal of Service Science and Management, 12, 277-292.

https://doi.org/10.4236/jssm.2019.123019

Received: June 19, 2018

Accepted: March 17, 2019

Published: March 20, 2019

Copyright () 2019 by author(s) and Scientific Research Publishing Inc. This work is licensed under the Creative Commons Attribution International License (CC BY 4.0).

http://creativecommons.org/licenses/by/4.0/

\begin{abstract}
The study examined the effect of distributive justice on customer post-complaint behaviour. The need for this study has become very demanding because a dissatisfied customer will imply that the company runs risk of operating at reduced state of future revenue stream accruable to the focal company. Data were drawn through questionnaire from 200 employees of 66 fast food firms in Rivers State. Descriptive and inferential statistics were utilized in analysing the data. The study found that distributive justice has a positive and significant relationship with customer post-complaint behaviour. In view of the above findings, the study concludes that customers who experience dissatisfaction will be willing to enact positive post-complaint behaviours if the firm addresses their issues satisfactorily; and recommend amongst others that management of fast food firms should be key in effective distributive justice in order to drive customers towards positive post-complaint behaviour.
\end{abstract}

\section{Keywords}

Distributive Justice, Customer Post-Complaint Behaviour, Word-of-Mouth, Fast Food Industry, Commitment, Nigeria

\section{Introduction}

Understanding how customers evaluate their service experience in the highly competitive and involved service sector has increased manager's concern [1]. Customers set the limit of service quality if companies are able to meet their expectations. All the same, as a result of the nature of services (intangibility, inseparability, perishability and heterogeneity), service failure is certain to happen. It is also relevant to state that most customers do not tender complaint after expe- 
riencing service disappointment or dissatisfaction, but launch their exit. Customer complaint behaviour identifies with the reactions turned on by perceived dissatisfaction that is neither psychologically approved nor expeditiously dissonance in product consumption [2]. Complaint handling systems are the ultimate test for a company's customer orientation as they strive to create satisfactory resolutions to customer concerns [3]. Conventionally, when a customer is dissatisfied, the company runs risk of losing all future revenue streams that could be generated through repeat business by the customer. In addition, the company also risks losing possible revenue streams of the customers' friends and relatives who may decide not to do business with the company based on negative word of mouth [4]. Accordingly, consumer dissatisfaction is the function of the inequality between expected or achieved performance. Consequently, it asserts that effective complaint handling not only enhances the likelihood of repurchase, but also that it limits the spread of potentially damaging negative word of mouth [5].

The tendency of companies to be broad minded to customer's complaint is the basis for companies' profitability and maintainability. Productive complaint handling heightens re-purchase intentions reduces unfavourable word-of-mouth, a raise on positive word-of-mouth and may result in even massive customer loyalty and satisfaction than if service failure had not taken place at all [6].

Complaints are usual cost of any service activity because "mistakes are necessary feature of all human endeavors including service delivery" [7]. Recently the importance of customer complaint handling has been recognized. Ineffective handling of buyers' complaints increases their dissatisfaction and harms a marketer's reputation. In a service recovery perspective, complaints expressed to the firm can also be seen as an opportunity to strengthen the bond between the customer and the firm [8].

Customer satisfaction is increasingly used for standard of customer related activities and a superiority standard for any business organization. Unhelpful service encounters or service failures may cause the defection of customers hence, understanding the service recovery process is fundamental. Although service failure has the potential to destroy customers' loyalty, the successful implementation of service recovery strategies may prevent the defection of customers who experience service failure [9].

An unfavorable service experience can create "terrorists" that is, customers who are so dissatisfied that they actively and systematically seek opportunities to criticize or damage the company or its reputation. In this context, it is imperative for companies to pay attention to customers and their satisfaction after experiencing services [10]. Also, a major part of these affairs achieved through analysis and investigations of complaints and their reasons. Everybody that complains is more likely to buy again. Thus, recognition of complaints behaviour for each company will be needed and that is a crucial factor. In this study, effort is made to determine how customers' perception of companies' fairness in handling complaints relates with post-complaint behaviors' of customers. To this end, distributive, procedural and interactional justices are evaluated as di- 
mensions of distributive justice. Distributive Justice ranges to tangible compensation given to a dissatisfied customer.

\subsection{Statement of the Problem}

The advantages of customer satisfaction and the prices of customer dissatisfaction on firms have been extensively researched by scholars. The yearning of every firm therefore, is to secure the long-term preference of customers and to maximize the benefits that accrue there from. This is not just an ideal; it is an expected norm for all players in an industry. However, it is common to see or hear of fast food firms that are struggling to cope; spending so many resources, but achieving less than desired. Though several factors could be culprits for this phenomenon, managers are apt to look for solutions in the most unlikely programmes or activities, thus, often plummeting into further uncertainties or record short-lived successes.

The fast-food industry is a service dominant one. It is thus not immune to instances of service failure that characterize service deliveries. Hence, customer complaints will also be an integral facet of the industry. However, much is not known about the distributive justice of firms in the industry, and how such practices assuage customers when they experience service glitches. It may not be out of place to suspect that fast-food firms do not have enshrined distributive justice that deliver post-complaint satisfaction to customers; which may have resulted to the low level of customer loyalty experienced by firms in the industry. The fast-food industry in Nigeria is associated with heavy advertising expenditure. This testifies to the fact that firms in the industry are always scouting for customers. It also attests to the fact that fast-food customers do not exhibit loyalty in the industry [11].

A number of studies have thus been carried on complaint handling and post-complaint behavior [12]. However, most of these studies offer little help to fast-food firms in Nigeria because most were conducted in other sectors of the economy or were alien to Nigeria. Other factors ranging from differences in economic conditions, level of enlightenment of consumers and disparities in regulatory frameworks makes it impracticable to implement the findings of these studies in the Nigerian context. Also, most of the studies conducted on distributive justice and post-complaint behaviour did not use distributive justice as a moderating variable or take their bearing from the equity theory, attribution theory and the prospect theory.

Thus, with a view to complementing the body of knowledge on distributive justice and post-complaint behaviour, the current study seeks to investigate the link between distributive justices as a dimension of complaint handling. Therefore, the purpose of the study is to empirically investigate the extent to which distributive justice affects customer post-complaint behaviour.

\subsection{Research Question}

To what extent does distributive justice affect customer post-complaint beha- 
viour?

\subsection{Hypotheses}

Based on the research question raised, the following hypotheses were formulated to guide the study:

$\mathrm{Ho}_{1}$ : There is no significant relationship between distributive justice and repeat purchase.

$\mathrm{Ho}_{2}$ : There is no significant relationship between distributive justice and word-of-mouth.

$\mathrm{Ho}_{3}$ : There is no significant relationship between distributive justice and commitment.

\section{Conceptual Underpinning}

The concept of justice is taken as vital and fundamental by humanity. According to [13] equity theory posits that individuals make comparisons of their input-output ratio with those of others so as to ascertain the degree of fairness. When individuals notice unfairness, they improve upon their attempts, or alter their perceptions concerning inputs or output outcomes so as to gain exact equity. Distributive justice refers to what customers consider to be just with respect to the allocation of resources by the firm to rectify and compensate for a service failure. Distributive justice has generally focused on the tangible compensation given to the dissatisfied customer, including refunding money, discounts, changing the goods or services [14]. Distributive justice refers to "the allocation of costs and benefits in achieving equitable exchange relationships".

Distributive Justice is decisions on the allocation of rewards based on individual's commitment to an exchange relationship, stipulates that a person's reward in an exchange relationship should be commensurate to the investment [15]. Customers experience about concrete outcome of service recovery attempts involving compensation, discount, coupon, free exchange etc. Hence, distributive justice indicates that the irregularity in the degree of outcomes to inputs between seller and buyer will metamorphous into perceived unfairness. Distributive justice based on equity suggests that customer seeks their outcomes to maximize benefits and bring losses to minimal. [16] defined distributive justice as the distribution of cost and benefits with particular reference to transactional relationships. In essence distributive justice concerns itself with the level and nature of apologies and compensations relying on the premise that individuals anticipate that their investment be commensurate to their returns. Distributive justice refers to the given out of tangible resources by a firm to remedy and compensate for failing to render a service in a service failure/recovery perspective, it is known as the perceived fairness of the service/recovery aftermath [17].

Issues on distributive justice are all-encompassing throughout society since it is present in every situation that attracts exchanges between people. In the consumer complaint perspective, distributive justice focuses on the perceive fairness 
of remedy meted out to consumers to settle their complaint. Satisfaction would be presented when customers perceived the outcome to input ratio is commensurately fair or greater for the customers. Contrarily, [18] contends that against the majority of customers who anticipates the same outcome just as everyone else, a loyal customer would anticipate a preferential outcome in the service recovery procedure to attain justice. Distributive justice focuses on the perceived fairness of the outcome of the service encounter which could be referred to as the allocation or benefits and costs. In effect, distributive justice is concerned with the level and nature of apologies and compensations, and it lies on the premise that individuals expect their investment to be proportional to their return. When customers felt that they did not receive a fair outcome, the explanations behind the unfair evaluations are due to the insufficient reimbursement for the negative emotions that endured, or that companies have failed to acknowledge and compensate the costs customers incurred in order to solve the problem.

Researchers in marketing have shown that complaint handling activities that involve tangible compensation in the form of reimbursement, product service replacement, credit, apology, repair, refund, compensation positively affect customers perception of distributive justice. In the organizational literature, distributive justice refers to the perceived fairness of the outcome that employees receive regarding pay or promotions in relation to the amount of effort they have put into their job. In terms of exchange relationships, distributive justice deals with how the profits are shared and how the benefits and burdens are divided or allocated two parties.

\subsection{Distributive Justice}

Complaints should be looked at in a constructive, positive and professional manner, mainly because complaints handling can make use of information for quality improvements and have a great impact on customers' retention [19]. Complaints and the processes for handling them are important issues for service providers because they have the potential of eliciting an adverse effect on customer satisfaction and loyalty. Research on customer post complaint behaviour has focused mainly on the customer's attitude towards complaining, attribution of blame and the likelihood of a successful solution. [20] recommends effective generic guidelines in the successful resolution of complaints. They include acting expediently to resolve the issue; acknowledging mistakes without being defensive; not arguing with customers; openness in solving the problem; considering the possibility of compensation by trying to regain the goodwill of customers. Despite the fact that organizations appreciate the importance of managing complaints, overall customer satisfaction after a failure has not improved. Organizations should encourage dissatisfied customers to complain so that they can solve the problem and retain the customer. Unfortunately, organizations that do not rise to the challenge of handling complaint are turning down the important op- 
portunity of reclaiming and improving a relationship with aggrieved customers, owing to the apparent importance of effective complaints handling, there is a research gap on how companies should treat all complaining customers to achieve customer satisfaction. Companies strive in the direction of improve service quality, but overall customer satisfaction remains a problem in organizations.

\subsection{Theoretical Framework (Equity Theory)}

Equity theory proposes that customer's attitudes and behaviours are influenced by the appraisal of their contribution and the recompense they take. Equity theory stresses that individuals are interested in the ultimate levels of outcomes and fairness of outcomes for both parties participating in a business deal [21]. Equity theory also implies that the existence of inequality creates pressures, which will commensurate weightiness of inequality. Adam [22] stated that, "the presence of inequality will motivate the perceivers to achieve equity or to reduce inequality; and the strength of motivation to do so will vary directly with the magnitude of inequality experienced". Equity stands as the foremost distribution code for estimating exchange fairness. When inequality within a transaction is acknowledged, the parties involved in activities that minimize pressure, or parties involved in activities that minimize pressure, the party of a relatively deprived position may elect to quit the relationship.

According [23] customers' estimation of recovery can be clarified through equity theory. Equity theory becomes useful in a situation where an exchange occurs and is therefore compatible in endeavors to expound how recovery is arrived at. The perceived justice component of equity theory will direct customers to estimate if they have received a fair recovery strategy or not. Justice theory has been made manifest in many conflict resolution settings that has to do with buyer-seller, employee-management, marriage and legal disputes, and it has indicated vigorousness in construing responses to conflicts which involves complaint [24]. This paper applies the equity theory as the main theoretical foundation guiding it. This is so because it is used to resolve conflicts amicably more so with consumers.

\section{Empirical Studies}

\subsection{Distributive Justice and Repeat Purchase}

Distributive justice is seen as "outcome" justice that lays emphasis on "equity" issues in consumer's mind, [25] asserts that compliant handling does not derive judgment from satisfaction with the organization's responses, but by post complaint customer behaviour that are noticeable in repurchase intentions and word-of-mouth intension. Post-purchase intentions are normally perceived as an indicator for predicting consumers' future behaviours [26]. Repeat purchase is then seen as a consumer's intentions commitment to repurchase a product or service and portrays their experience linked with purchasing or utilization of the 
product or service. For most service organizations, economic efficiency is a function of an ability to maintain long-term relationship with customers who patronize their products constantly [27].

Apprehending the reasons customers repeatedly buys from a service firm represent an issue of significant magnitude because service research has in these contemporary times identified a number of potential drivers of repeat purchase. In view of the above analysis, the study's first tentative statement becomes- $\mathrm{Ho}_{1}$ : There is no significant relationship between distributive justice and repeat purchase.

\subsection{Distributive Justice and Word-of-Mouth}

When complainants are treated with courtesy and respect even a partial refund, exchange, or discount can have a favorable impact drawing from word-of-mouth experience there by leading to patronage behavior. In general, according to [28] complainants who experience higher levels of distributive justice are more likely to patronize the retailer and are less likely to engage in negative word-of-mouth behavior (and vice-versa).

Contrary to expectations, Gruberfirst [29] found that distributive justice had no effect on subjects' patronage intentions or on their word-of-mouth intentions. Although the high and low distributive justice conditions were perceived accordingly, having to come back the next day to talk to the manager apparently was of little consequence compared to the manner in which the complainant was treated and the amount of the exchange or discount that was offered. In their own study found that complainants may understand the need to speak to the store manager (especially in nonroutine situations), and realize that the manager cannot always be at the store. Hence, having to come back to the store the next day is not so unreasonable as to cause complainants to engage in negative word-of-mouth or to vow never to patronize the retailer. The key finding of [30] study revealed that distributive justice explained a significantly greater percentage of the variance of subjects' post-complaint intentions than did distributive justice. Also, these findings point to the importance of training retail employees how to respond to customer complaints. Therefore, the study's second conjectural statement is- $\mathrm{Ho}_{2}$ : There is no significant relationship between distributive justice and word-of-mouth.

\subsection{Distributive Justice and Commitment}

From the works of [31] marketers have been made to know that by understanding the complaint process and the customer complaint behaviour, the service company can learn how to reduce the impact of an unfavourable service experience or complaint. Unhappy customers often voice their displeasure in the form of disloyalty and noncommitment to other current and potential customers.

[32] confirms that service and complaint handling enhance customer satisfac- 
tion and that service and complaint handling are the most important customer satisfaction determinants in banks. Customer commitment is by-product of customer satisfaction attained through effective and efficient service delivery. According to [33] satisfaction can be restored, but not enhanced, when a complaint is properly handled, which is why attempts to make it right the first time are preferred. Gruber first, [34] found that complaint handling through distributive justice system also improves customer commitment and satisfaction. In addition, [35] findings are supported by [36] who investigated the relationship between customer complaints and commitment and found that by encouraging customers to complain their commitment and satisfaction especially amongst dissatisfied customers are increased.

To exploit this capital, organizations must design, build, operate and continuously upgrade systems for managing customer complaints. Therefore, customer centricity in the 21 st century in view of competitive market place occasioned by globalization should to be the goal of every bank world-wide and more so in developing countries like Kenya. Complaint handling can be a significantly superior investment for a service company and can generate 30 - 150 percent return on investment [36]. Accordingly, the third hypothesis for the study is- $\mathbf{H o}_{3}$ : There is no significant relationship between distributive justice and commitment.

\section{Methodology}

The aim of this study is to examine the extent of the relationship between distributive justice and customer post-complaint behaviour in the fast food industry in Rivers State. The study adopted a correlation research design to determine the extent of relationship between distributive justice and customer post-complaint behaviour. The population of the study consists of sixty-six (66) registered fast food firms in Rivers State. The simple random sampling technique was adopted to select 330 respondents from the registered fast food firms in Rivers State. The instrument for data collection was a structured questionnaire tagged "Distributive Justice and Customer Post-Complaint Behaviour Questionnaire (DJCPBQ)". The questions in the questionnaire were intended to collect data on the study variables for the purpose of testing facts on complaints handling practices and post complaint behaviour. The instrument was adjudged by experts to be reliable and valid. The research question was analysed using descriptive statistics while the hypotheses were analyzed using inferential statistics (Multiple Regression Analysis) with the aid of a crone programme (SPSS version 22.0).

\section{Results}

Research question one: Effect of Distributive justice on customer post-complaint Behaviour.

In order to establish the statistical significance of the independent variable on the dependent variable (customer post complaint Behaviour) regression analysis 
of ordinary least square estimate was employed to show the coefficient of determination also called $\mathrm{R}$ square as 747 . This implies that the combined effect of the predictor variable (Distributive Justice) explains $74.7 \%$ of the variables in customer post complaint behaviour 0.864 of fast food firms in Rivers State. The correlation coefficient of 0.864 indicates that the predictor variable has a strong and positive correlation with customer post complaint behavior (Table 1).

The Analysis of Variance (ANOVA) on Table 2 shows that the effect of distributive justice is statistically significant in explaining changes in customer post complaint behaviour in fast food firms in Rivers State. This is demonstrated by a $P$ value of 0.000 which is less than the acceptance critical value of 0.05 .

Table 3 shows that there is also a standardized coefficient of 0.864 which is perfect as well as corresponding $\mathrm{P}$ value (sig.) of 0.000 which is less than alpha (0.05). Therefore, we conclude that here is a significant effect of distributive justice on customer post complaint behaviour

\subsection{Relationship between Distributive Justice and Repeat Purchase Test of Hypothesis 1}

$\mathrm{Ho}_{1}$ : There is no significant relationship between distributive justice and repeat purchase.

Table 4 shows that the Pearson's $r=0.483$. Thus, shows that a moderate relationship exists between distributive justice and repeat justice. The sign of the

Table 1. Effect of distributive justice on customer post-complaint behaviour model summary.

\begin{tabular}{cccccc}
\hline Model & R & R Square & Adjusted Rsquare & STD Error & Sig. \\
\hline 1 & $0.864^{\mathrm{a}}$ & 0.747 & 0.662 & 0.628 & $0.000^{\mathrm{b}}$
\end{tabular}

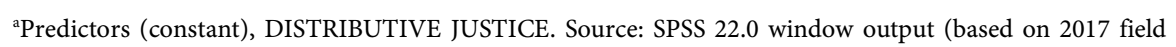
survey data).

Table 2. ANOVA.

\begin{tabular}{ccccccc}
\hline Model & & Sum of Squares & Df & Mean Square & F & Sig. \\
\hline 1 & Regression & $36,496,263$ & 1 & $3,496,263$ & 8.84184 & $0.000^{\mathrm{b}}$ \\
& Residual & 118,627 & 199 & 0.648 & & \\
& Total & $3,614,890$ & 200 & & &
\end{tabular}

Dependent Variable: Customer Post Complaint Behaviour. Predictors: (constant), DISTRIBUTIVE JUSTICE.

Table 3. Coefficients.

\begin{tabular}{ccccccc}
\hline & & \multicolumn{3}{c}{ Unstandardised Coefficients } & \multicolumn{3}{c}{ Standard Coefficients } \\
\cline { 3 - 7 } & & B & Std. Error & Beta & t & Sig. \\
\hline 1 & (Constant) & 096 & 076 & & 2.97 & 000 \\
& DISTIBUTIVE JUSTICE & 487 & 005 & 0.864 & 0.058 & 000 \\
\hline
\end{tabular}

Dependent Variable: CUSTOMER POST COMPLAINT BEHAVIOUR. Source: SPSS 22.0 Window Output (based on 2017 field survey data). 
Table 4. Correlation analysis showing the direction and strength of the relationship between distributive justice and repeat purchase.

\begin{tabular}{cccc}
\hline \multicolumn{3}{c}{ Correlations } \\
\hline Variables & Statistics & Distributive Justice & Repeat Purchase \\
\hline \multirow{2}{*}{ Repeat Purchase } & Pearson's correlation & 1.000 & $0.483^{* *}$ \\
& Sig. (2-tailed) & & 0.000 \\
& $\mathrm{~N}$ & 200 & 200 \\
Distributive Justice & Pearson's correlation Sig & $0.483^{* *}$ & 1.000 \\
& (2-tailed) & 0.000 & 200 \\
\hline
\end{tabular}

${ }^{* *}$ Correlation is significant at the 0.01 level (2-tailled).

correlation coefficient is positive, indicating that when distributive justice increases, repeat purchase also increases. This does not agree with the stated null hypotheses 1 (There is no significant relationship between distributive justice and repeat purchase).

Therefore, the researcher rejects the null hypothesis and accepts the alternative hypothesis that there is a significant relationship between distributive justice and repeat purchase.

The significant/probability value $(\mathrm{pv})=0.000<0.05$. Therefore, the researcher concludes that a significant positive relationship exists between distributive justice and repeat purchase, implying that when a company is perceived as applying distributive justice in handling complaint, this will in turn influence the customer to repeat the purchase of company's products.

\subsection{Relationship between Distributive Justice and Word-of-Mouth}

$\mathrm{Ho}_{2}$ : There is no significant relationship between Distributive justice and word-of-mouth.

Table 5 shows that the Pearson's $(r)=0.415^{\star *}$. This shows that a moderate relationship exists between distributive justice and word-of-mouth. The sign of the correlation coefficient is positive, indicating that when distributive justice increases, word-of-mouth also increases. This does not agree with the stated null hypothesis 2 (There is no significant between distributive justice and word-of-mouth). The significant/probability value $(\mathrm{pv})=0.001<0.05$. Therefore, the researcher concludes that a significant positive relationship exists between distributive justice and word-of-mouth, implying that when a company is perceived as applying distributive justice in handling complaint, this will subsequently affect word-of-mouth positively.

\subsection{Relationship between Distributive Justice and Commitment}

$\mathrm{Ho}_{3}$ : Correlation Analysis showing the direction of relationship between Distributive Justice and Commitment.

Table 6 shows that Pearson's $(r)=0.461^{\star *}$. Thus, shows that a moderate relationship exists between distributive justice and commitment. The sign of the 
Table 5. Correlation analysis showing the direction and strength of the relationship between distributive justice and word-of-mouth.

\begin{tabular}{cccc}
\hline \multicolumn{3}{c}{ Correlations } \\
\hline Variables & Statistics & Distributive Justice & Commitment \\
\hline \multirow{3}{*}{ Commitment } & Pearson's correlation & 1.000 & $0.415^{* *}$ \\
& Sig. (2-tailed) & & 0.000 \\
& $\mathrm{~N}$ & 200 & 200 \\
Distributive Justice & Pearson's correlation Sig & $0.415^{* *}$ & 1.000 \\
& $(2$-tailed) & 0.000 & $\cdot$ \\
& $\mathrm{N}$ & 200 & 200 \\
\hline
\end{tabular}

${ }^{* *}$ Correlation is significant at the 0.01 level (2-tailed).

Table 6. Correlation analysis showing the direction and strength of relationship between distributive justice and commitment.

\begin{tabular}{|c|c|c|c|}
\hline \multicolumn{4}{|c|}{ Correlations } \\
\hline Variables & Statistics & Distributive Justice & Commitment \\
\hline \multirow{3}{*}{ Commitment } & Pearson's correlation & 1.000 & $0.461^{\star *}$ \\
\hline & Sig. (2-tailed) & & 0.000 \\
\hline & $\mathrm{N}$ & 200 & 200 \\
\hline \multirow{3}{*}{$\begin{array}{l}\text { Distributive } \\
\text { Justice }\end{array}$} & Pearson's correlation Sig & $0.461^{\star *}$ & 1.000 \\
\hline & (2-tailed) & 0.000 & . \\
\hline & $\mathrm{N}$ & 200 & 200 \\
\hline
\end{tabular}

${ }^{* *}$ Correlation is significant at the 0.01 level (2-tailed).

correlation coefficient is positive, indicating that when distributive justice increases, customer commitment also increases. This does not agree with the stated null hypothesis 3 (There is no significant relationship between distributive justice and commitment), therefore the researcher rejects the null hypothesis and accept the alternative hypothesis that there is a significant relationship between distributive justice and commitment.

The significant/probability value $(\mathrm{pv})=0.00<0.05$. Therefore, the researcher concludes that a significant positive relationship exists between distributive justice and commitment, implying that when a company is perceived as applying distributive justice in complaint handling, it subsequently influences customer commitment to that company.

\section{Discussion}

Relationship between Distributive Justice and Repeat Purchase, Word-of-Mouth and Commitment. Basically, distributive justice is a substantive factor or determinant of customer post-complaint behaviour. Distributive justice is employed to repair and indemnify for rendered service in order to address the responses activated by the apprehensive dissatisfaction that is not disremembered in the consumption of products or service [25]. A very vital step in guaranteeing repeat purchase is to understand complaint from customers and address appropriately. As it is in our expectation and indeed supported by our findings, distributive 
justice has a moderate, positive and significant relationship with repeat purchase, word-of-mouth and commitment.

Thus, the first hypothesis sought to determine the association between distributive justice and repeat purchase using the Pearson's product moment correlation analysis. The hypothesis was stated in the null form, statistically tested and rejected. The alternative hypothesis that distributive justice is positively related to repeat purchase was accepted. The concept of distributive justice as measured in this study dealt with issues on the availability of high-quality allocation of rewards depending on a Person's commitment to an exchange process. To satisfy customers and make them loyal is judged by post complaint behaviours such as repeat purchase. [30] posits that repeat purchase focuses on the construct that customers have the intention to buy a given product repeatedly after deriving satisfaction from initial use or experience. Given that the customer experience service failure or inadequate product, the level of justice distributed to his complaint makes his post complaint behaviours as repeat purchase positive. From our findings, we understand that when complaints are positively handled, it rubs on positively on customers post complaint behaviour. Our findings agree and support the findings of [27] that complaint handling influence significantly post complaint satisfaction.

Actually, companies delivering sound distributive justice programmes as perceived by the customers have remained a major driver of repeat purchase. The dispensation of distributive justice alone is not enough to sustain the required level of customer patronage, but it is a basis for the execution and achievement of overall customer patronage.

It was hypothesized in the second hypothesis that distributive justice does not positively related to word-of-mouth, the outcome of the test revealed that distributive justice moderately, significantly and positively relates with word-of-mouth. It is possible to argue that distributive justice triggers word-of-mouth of a specific product over others, and this is based on subjective judgment. Word of mouth according to [28] distributive justice connotes the act of informing others about a satisfactory or unsatisfactory experience of a service. From time unknown, people have significantly made decisions and developed daily preferences based on word of mouth communication. When customers complaints are handled with courtesy and even a partial refund, exchange, or discount given, it can lead to a favourable impact that elicits word-of-mouth that will result to patronage behaviour. Our findings are not consistent with [34] findings that distributive justice had no effect on subject's patronage intentions or in their word-of-mouth intentions. It is important to note that, it is only when complaints are treated with courtesy and respect that distributive justice has a positive effect on post-complaint behaviour drawn by word-of-mouth. To achieve this, the focal companies are to focus on the constructs identified in this study that is, provide high quality product, genuine, functional and durable products, and above all give customers what they consider to be just in line with the allocation of resources by the firm to remedy and compensate for service failure, then will cus- 
tomers have a positive attitude towards their companies.

In the third hypothesis, the relationship between distributive justice and commitment was found to be moderate, significant and positive thus, $\mathrm{Ho}_{3}$ was rejected and $\mathrm{Ha} 3$ accepted. The opinions of the participating firms confirmed that distributive justice represents the perceived fairness of the outcome of a service encounter that leads to the allocation of benefits to compensate for service failure or service not rendered properly. It relates to the level and nature of apologies and compensations given to individuals who complained after service failure. This single art leads to customer satisfaction. Customer commitment is a bye-product of customer satisfaction that emanate through effective and efficient service delivery. Our finding therefore, suggests that customers show commitment to companies who handles their complaints efficiently and to their satisfaction. Our research finding is supported by [30] findings that complaint handling through distributive justice system improves customer commitment and satisfaction. In conclusion, distributive justice has positive influence on customers' repeat purchase, word-of-mouth and commitment.

\section{Conclusions and Recommendations}

This work focused on investigating the relationship between distributive justice and customer post complaint behaviour of fast food firms in Rivers State. The following conclusions can be drawn from the discussion of our findings and from the hypotheses. The study attempted to assess the extent to which responses from the respondents on distributive justice explain customer post complaint behaviour. It was assumed that such information would facilitate the formulation of appropriate complaint handling policies and marketing strategies by fast food firms. It is evident from the findings that there is implicit relationship between attributes of distributive justice and customer post complaint behaviour. Thus, given knowledge of the importance that firms attached to the various attributes of distributive justice, it will be fairly possible for firms to predict the outlet where consumers would prefer to do their business. Management should be key in distributive justice to customer post complaint behaviour, since the study unveiled a statistically significant relationship between the variables. Fast food firms should be skilled in packaging distributive justice to relate genuinely with customer post complaint behaviour. This implication is necessary because the study revealed that distributive justice was the most significant dimension of that predicts customer post complaint behaviour.

Management should position strategically, the two dimensions of complaint handling practices (distributive justice and interactional justice) to customer post complaint behaviour, since the study unveiled a statistically significant relationship between them. Management should be skilled in packaging distributive justice and interactional justice to relate genuinely with customer post complaint behaviour. This implication is necessary because the study revealed that distributive justice and interactional justice were the most significant dimensions of 
complaint handling practices that predicts customer post complaint behaviour.

\section{Conflicts of Interest}

The authors declare no conflicts of interest regarding the publication of this paper.

\section{References}

[1] Gruber, I., Szmigin, I. and Voss, R. (2009) Handling Customer Complaints Effectively. A Comparison of the Value Maps of Female and Male Counterparts. Managing Service Quality, 19, 636-656. https://doi.org/10.1108/09604520911005044

[2] Gruber, T. (2011) I Want to Believe They Really Care: How Complaining Customers Want to Be Treated by Frontline Employees. Journal of Service Management, 22, 85-110. https://doi.org/10.1108/09564231111106938

[3] Gruber, T., Szmigin, I. and Voss, R. (2006) The Desired Qualities of Customer Contact Employees in Complaint Handling Encounters. Journal of Marketing Management, 22, 619-642. https://doi.org/10.1362/026725706777978721

[4] Wali, A.F. and Nwokah, N.G. (2017) Aviation Customers' Journey, Who Cares? Managing Customer Experiences with Customer Relationship Management Strategy: Insight into Nigerian Customers' Perspectives. Journal of Global Scholars of Marketing Science, 27, 123-135. https://doi.org/10.1080/21639159.2017.1283795

[5] Michael, B. and Menter, M.L. (2008) The Service Recovery Paradox: True but Overrated? International Journal of Service Industry Management, 19, 441-457. https://doi.org/10.1108/09564230810891897

[6] Micheal, S., Bowen, S. and Johnson, R. (2009) Why Service Fails? Tensions among Customer, Employee and Process Perspective. Journal of Service Management, 20, 253-273. https://doi.org/10.1108/09564230910964381

[7] Tax, S.S. and Brown, S.W. (2000) Service Recovery: Research Insights and Practices. In: Swartz, T.A. and Lacobucci, D., Eds., Handbook of Services Marketing and Management, Sage Production, Thousand Oaks, California.

[8] Tax, S.S. Brown. S.W. and Chandrashekaran, M. (1998) Customer Evaluation of Service Complaint Experiences: Implications for Relationship Marketing. Journal of Marketing, 62, 60-76. https://doi.org/10.1177/002224299806200205

[9] Chaffey, D. and Smith, P.R. (2013) E-Marketing Excellence: Planning and Optimizing Your Digital Marketing. 4th Edition, Taylor \& Francis, London. https://doi.org/10.4324/9780203082812

[10] Chanthinok, K., Ussahawanitichakit, P. and Jhundraindra, P. (2015) Allied Academies International Conference. Proceedings of the Academy of Marketing Studies (AMS), 20, 35-52.

[11] Casado, A., Nicolau, J.H. and Mas, F.L. (2011) The Harmful Consequences of Failed Recoveries in the Banking Industry. International Journal of Bank Marketing, 29, 32-49. https://doi.org/10.1108/02652321111101365

[12] Tronvoll, B. (2007) Complainer Characteristics When Exit Is Closed. International Journal of Service Industry Management, 18, 25-51. https://doi.org/10.1108/09564230710732885

[13] Tronvoll, B. (2012) A Dynamic Model of Customer Complaint Behaviour from the Perspective of Service Dominant Logic. European Journal of Marketing, 46, 284-305. https://doi.org/10.1108/03090561211189338 
[14] Lerman, D (2006) Consumer Politeness and Complaining Behaviour. Journal of Services Marketing, 20, 92-100. https://doi.org/10.1108/08876040610657020

[15] Johnston, R. and Michel, S. (2008) Three Outcomes of Service Recovery: Customer Recovery, Process Recovery and Employee Recovery. International Journal of Operations and Production Management, 28, 79-99. https://doi.org/10.1108/01443570810841112

[16] Ateke, B.W. and Kalu, S.E. (2016) Complaint Handling and Post Complaint Satisfaction of Customers of Entries in Port Harcourt, Nigeria. International Journal of Research in Business Studies and Management, 3, 16-26.

[17] Atalik, O. (2007) Customer Complaints about Airline Service: A Preliminary Study of Turkish Frequent Flyers. Management Research News, 30, 409-419. https://doi.org/10.1108/01409170710751908

[18] Osarenkhoe, A. and Komunda, M.A. (2013) Redress for Customer Dissatisfaction and Its Impact on Customer Satisfaction and Customer Loyalty. Journal of Market Development and Competitiveness, 7, 102-114.

[19] Crie, D. (2003) Consumers Complaint Behaviour: Taxonomy, Typology and Determinants: Towards a Unified Ontology. Journal of Database Marketing \& Customer Strategy Management, 11, 60-79. https://doi.org/10.1057/palgrave.dbm.3240206

[20] Hoban, P.R. and Bucklin, R.E. (2015) Effects of Internet Display Advertising in the Purchase Funnel: Model-Based Insights from a Randomized Field Experiment. Journal of Marketing Research, 52, 375-393. https://doi.org/10.1509/jmr.13.0277

[21] Adams, S.J. (1965) Inequity in Social Exchange: Advances in Social Psychology. Academic Press, New York, 267-299. https://doi.org/10.1016/S0065-2601(08)60108-2

[22] Pinto, M.B. and Yagnik, A. (2017) Fit for Life: A Content Analysis of Fitness Tracker Brands Use of Facebook in Social Media Marketing. Journal of Brand Management, 24, 49-67. https://doi.org/10.1057/s41262-016-0014-4

[23] Nwokah, N.G. and Poi, E.L. (2016) Customers' Involvement and Retention of Deposit Money Banks in Port Harcourt. Journal of Marketing and Consumer Research, 29, 53-66.

[24] Ateke, B.W. and Harcourt, H. (2017) Perceived Satisfaction with Organizational Response to Complaint and Repeat Purchase Intention. International Journal of Economics and Business Management, 3, 11-24.

[25] Ombudsman Western Australia (2017) Effective Handling of Complaints Made to Your Organisation-An Overview. http://www.ombudsman.wa.gov.au/Publications/Documents/guidelines/Effective-h andling-of-complaints-made-to-your-organisation.pdf

[26] Nwokah, N.G. and Gladson-Nwokah, J. (2013) Delivery Customer Experience Management in the UK and Nigeria Aviation Industry. Interdisciplinary Research Journal, 3, 72-100.

[27] Kau, A.K. and Loh, E. (2006) The Effects of Service Recovery on Consumer Satisfaction: A Comparison between Complainants and Non-Complainants. Journal of Services Marketing, 20, 101-111. https://doi.org/10.1108/08876040610657039

[28] Kelly, S.W., Hoffman, K.D. and Davis, M.A. (1993) A Typology of Retail Failure \& Recovery. Journal of Retailing, 59, 71-82. https://doi.org/10.1016/0022-4359(93)90016-C

[29] Hamilton-Ibama, E.L. and Nwokah, N.G. (2016) Internal Communication and 
Market Orientation of Mobile Telecommunication Companies in Nigeria. $\mathrm{NeW} \mathrm{Me}$ dia and Mass Communication, 55, 33-48.

[30] Nwokah, N.G. (2009) Customer-Focus, Competitor-Focus and Marketing Performance. Measuring Business Excellence: The Journal of Organizational Performance, 13, 20-28.

[31] Lilien, G.L. (2016) The b2b Knowledge Gap. International Journal of Research in Marketing, 75, 196-210. https://doi.org/10.1016/j.ijresmar.2016.01.003

[32] Didia, J.U.D. and Nwokah, N.G. (2015) Customer Service Integration and Business Performance in the Telecommunication Industry in Nigeria. Journal of Marketing and Consumer Research, 13, 99-108.

[33] Kanovska, L. and Tomaskova, E. (2012) Inter-Functional Coordination at Hi-Tech Firms. Engineering Economics, 23, 70-76. https://doi.org/10.5755/j01.ee.23.1.1224

[34] Nwokah, N.G. and Didia, J.U.D. (2015) Customer Relationship Management and Marketing Performance: The Study of Food and Beverages Firms in Nigeria. European Journal of Business and Management, 7, 85-95.

[35] Nwokah, N.G., Amadi, R.N. and Oruene, F.M. (2009) Consumers Preference for FM Stations in Port Harcourt: A Survey of UST Students. European Journal of Scientific Research, 38, 514-520.

[36] Nwokah, N.G. and Maclayton, D.W. (2006) Customer Focus and Business Performance: The Study of Food and Beverages Organizations in Nigeria. Measuring Business Excellence: The Journal of Organizational Performance Management, 10, 65-76. 